\title{
The Dominant Factors of Scabies Incidence in Two Islamic Boarding School Students, South Sumatera, Indonesia
}

\author{
Yessi Arisandi ${ }^{1}$, Chairil Anwar ${ }^{2}$, Salni $^{3}$, Dadang Hikmah Purnama ${ }^{4}$, Novrikasari ${ }^{5}$ dan \\ Ahmad Ghiffari ${ }^{5}$ \\ ${ }^{1}$ Department of Environment, Postgraduate Students of Postgraduate, Universitas Sriwijaya \\ ${ }^{2}$ Department of Parasitology, Faculty of Medicine, Universitas Sriwijaya, Palembang, Indonesia, \\ Palembang, Indonesia \\ ${ }^{3}$ Department of Biology, Faculty of Science, Universitas Sriwijaya \\ ${ }^{4}$ Department of Sociology, Faculty of Social and Political Science, Universitas Sriwijaya \\ ${ }^{5}$ Department of Parasitology, Faculty of Medicine, Universitas Muhammadiyah Palembang, \\ Palembang, Indonesia \\ chairi153@fk.unsri.ac.id
}

\begin{abstract}
Scabies is a skin disease caused by infestation and sensitization towards Sarcoptes scabiei. It occurs easily in moist and densely-populated vicinities. This research was conducted to analyze the relationship between residential density and personal characteristics towards the incidences of scabies among students of boarding school Raudatul Ulum and Mustaqimus Sunnah, South Sumatra. This research was an epidemiological method using cross-sectional analytic approach, conducted in July 2018. The populations were all students of boarding school and the samples selected were 93 respondents with proportional random sampling. The measuring instruments were cardinal scabies physical diagnostic and questionnaire of demographic interviewing. Obtained results were then analyzed with Chi-Square, Logistic Regression Statistical Tests, and correspondence analysis. The result of scabies prevalence was $59,6 \%$ and $56,5 \%$ respectively. Logistic Regression testing result yielded the free variable bearing the most dominant influence towards scabies incidence, which was the residential density (OR: 5.850 95\% CI: 2.369-14.445). The significant relationship towards the occurrence of scabies should be further investigated in order to prepare for elimination programs.
\end{abstract}

\section{Introduction}

Scabies is a common contagious parasitic skin disease and a public health problem, mainly in tropical and subtropical countries [1,2]. Hundreds of millions of people suffer from the infestation in impoverished urban and rural communities worldwide [3,4]. Outbreaks of scabies in closed groups have been reported not only from high-income countries, but the disease is more common in resource-poor communities in low and

*Coressponding author : chairi153@,fk.unsri.ac.id 
middle-income countries [5,6]. High prevalence and re-infestations in endemic settings are correlated with armed conflicts, homelessness, crowding, and communal use of clothes, beds, and pillows [7-9]. Between $18 \%$ and $70 \%$ of people are reported to be affected in resource-limited communities in India, on South Pacific islands, and in Australian Aboriginal communities [1,10,11]. Severe morbidity is quite common, such as abscess formation, lymphadenopathy, and post-streptococcal glomerulonephritis [10,12,13].

Control and prevention strategies by chemotherapy require public health services and home resources $[2,14]$. The actual prevalence of scabies disease is unclear, that the severe morbidity is often underlooked [14,15]. Scabies is still neglected disease $[13,15,16]$. General Hospital of South Sumatra noted that in 2007-2011 the percentage was only $6.32 \%-9.38 \%-4.36 \%-4.08 \%-5.13 \%$ respectively, of the total scabies cases of skin diseases infection per year [17]. To provide on the epidemiology and to analyze the relation to it's with personal characteristics and environment facility, a cross-sectional school-based scabies infestation was conducted in crowded suburban school in South Sumatra Indonesia.

\section{Materials and Methods}

This cross-sectional study aimed to find out the relationship between the free variables: characteristics of respondents (age, gender, education, and place of study), and residential density. Research conducted in July 2018 at boarding school. The population of the research was all students boarding schools with a selected sample of 93 respondents using the proportional random sampling.

\subsection{Measuring Instruments}

Primary data was collected through interviews, observation, physical examinations, and of residential density by using a questionnaire, checklist and measuring instrument. Secondary data taken was a figure in the region of scabies in district health and clinic reports of boarding school.

\subsection{Statistics Analysis}

Data analysis was performed by using a statistical test of Chi-Square and logistical regression with $95 \%$ degree of confidence to analyze the relationship between residential capacity and personal hygiene against scabies incidence in boarding school students.

\section{Results and Discussions}

The results were the two of four cardinal scabies cardinal sign and the analysis of its' relationship to environmental density and personal characteristics variables.

\subsection{Characteristic of Respondents}

Table 1 showed the respondents' characteristics, of 93 respondents. The age was around 14 years old, more participants were male and the junior high school student.

Table 1. Frequency Distribution of Respondents Based on Characteristics $(\mathrm{N}=93)$ 


\begin{tabular}{|c|c|c|}
\hline Variable & $\begin{array}{c}\text { Mean } \\
\text { Median }\end{array}$ & N \\
\hline Age (15 yo) & 47.3 & 44 \\
52.7 & 49 \\
\hline Male & 54.8 & 51 \\
\hline Female & 45.2 & 42 \\
\hline Junior High & 50.5 & 47 \\
\hline Senior High & 49.5 & 46 \\
\hline
\end{tabular}

Table 2 showed the environments' residential density, which showed more of the respondents lived in a not suitable condition.

Table 2. Frequency Distribution of Respondents Based on Residential Density ( $\mathrm{N}=93$ )

\begin{tabular}{|c|c|c|}
\hline Residential Density & N & \% \\
\hline Good $\left(4 \mathrm{~m}^{2} /\right.$ person) & 43 & 46.2 \\
\hline Not Good & 50 & 53.8 \\
\hline
\end{tabular}

Table 3 showed the prevalence of scabies with physical examination diagnostic $(\mathrm{N}=93)$

Table 3. The prevalence of Scabies $(\mathrm{N}=93)$

\begin{tabular}{|c|c|c|}
\hline Scabies & $\mathbf{N}$ & $\mathbf{\%}$ \\
\hline Positive & 54 & 58.1 \\
\hline Negative & 39 & 41.9 \\
\hline
\end{tabular}

\subsection{Analysis of Prevalence with Variables.}

The dominant factors of environmental sanitation and personal hygiene with scabies were the residential density, and respondents' age.

Table 4 showed the relationship between prevalence of Scabies with which Islamic boarding school, that showed no relation with the infestation of the parasite. Despite no significant relation, students who studied in Raudatul Ulum have a chance to being infestated 1.134 times compare to those studying in Mustaqimus Sunnah.

Table 4. The Relationship of which Islamic boarding school with Scabies Incidence $(\mathrm{N}=93)$

\begin{tabular}{|c|c|c|c|c|c|c|c|c|}
\hline \multirow{3}{*}{ Boarding school } & \multicolumn{4}{|c|}{ Scabies } & \multirow{2}{*}{\multicolumn{2}{|c|}{$\begin{array}{c}\text { Total } \\
\text { number }\end{array}$}} & \multirow{3}{*}{ p-value } & \multirow{3}{*}{ OR } \\
\hline & \multicolumn{2}{|c|}{ Positive } & \multicolumn{2}{|c|}{ Negative } & & & & \\
\hline & $\mathbf{n}$ & $\%$ & $\mathbf{n}$ & $\%$ & $\mathbf{n}$ & $\%$ & & \\
\hline Raudatul Ulum & 28 & 59.6 & 19 & 40.4 & 47 & 100 & 2 & 1.134 \\
\hline Mustaqimus Sunnah & 26 & 56.5 & 20 & 43.5 & 46 & 100 & 0.930 & $(0.497-2.585)$ \\
\hline
\end{tabular}

Table 5 showed the relationship between prevalence of scabies with gender, which resulted that male was more related to the infestation. Male has the chance of being infestated 5.580 times higher than the female students.

Table 5. The Relationship of Gender with Scabies Incidence $(\mathrm{N}=93)$

\begin{tabular}{|c|c|c|c|c|c|c|c|c|}
\hline \multirow{3}{*}{ Gender } & \multicolumn{4}{|c|}{ Scabies } & \multirow{2}{*}{\multicolumn{2}{|c|}{$\begin{array}{c}\text { Total } \\
\text { number }\end{array}$}} & \multirow{3}{*}{ p-value } & \multirow{3}{*}{$O R$} \\
\hline & \multicolumn{2}{|c|}{ Positive } & \multicolumn{2}{|c|}{ Negative } & & & & \\
\hline & $\mathbf{n}$ & $\%$ & n & $\%$ & n & $\%$ & & \\
\hline
\end{tabular}




\begin{tabular}{|l|c|c|c|c|c|c|c|c|}
\hline Male & 39 & 76.5 & 12 & 23.5 & 51 & 100 & & 5.850 \\
\hline Female & 15 & 35.7 & 27 & 64.3 & 42 & 100 & 0.001 & $(2.369-14.445)$ \\
\hline
\end{tabular}

Table 6 showed the relationship between prevalence of scabies with age, which resulted that younger age was more related to the infestation. Young students have the chance of being infestated 7.750 times higher than the older students.

Table 6. The Relationship of Age with Scabies Incidence $(\mathrm{N}=93)$

\begin{tabular}{|c|c|c|c|c|c|c|c|c|}
\hline \multirow{3}{*}{ Age } & \multicolumn{4}{|c|}{ Scabies } & \multirow{2}{*}{\multicolumn{2}{|c|}{$\begin{array}{c}\text { Total } \\
\text { number }\end{array}$}} & \multirow{3}{*}{ p-value } & \multirow{3}{*}{$O R$} \\
\hline & \multicolumn{2}{|c|}{ Positive } & \multicolumn{2}{|c|}{ Negative } & & & & \\
\hline & $\mathbf{n}$ & $\%$ & $\mathbf{n}$ & $\%$ & $\mathbf{n}$ & $\%$ & & \\
\hline$<15$ у.о. & 36 & 81.8 & 8 & 18.2 & 44 & 100 & & 7.750 \\
\hline$\geq 15$ у.о. & 18 & 36.7 & 31 & 63.3 & 46 & 100 & 0.003 & $(2.963-20.268)$ \\
\hline
\end{tabular}

Table 7 showed the relationship between prevalence of scabies with education level, which resulted that junior students were more related to the infestation. Junior students have the chance of being infestated 6.312 times higher than the senior high students.

Table 7. The Relationship of Education Level with Scabies Incidence $(\mathrm{N}=93)$

\begin{tabular}{|c|c|c|c|c|c|c|c|c|}
\hline \multirow{3}{*}{ Age } & \multicolumn{4}{|c|}{ Scabies } & \multirow{2}{*}{\multicolumn{2}{|c|}{$\begin{array}{c}\text { Total } \\
\text { number }\end{array}$}} & & \multirow[b]{2}{*}{$R$} \\
\hline & \multicolumn{2}{|c|}{ Positive } & \multicolumn{2}{|c|}{ Negative } & & & p-value & \\
\hline & $\mathbf{n}$ & $\%$ & $\mathbf{n}$ & $\%$ & $\mathbf{n}$ & $\%$ & & \\
\hline Junior High & 37 & 78.7 & 10 & 21.3 & 47 & 100 & & 6.312 \\
\hline Senior High & 17 & 26.7 & 29 & 63 & 46 & 100 & 0.001 & $(2.515-15.838)$ \\
\hline
\end{tabular}

Table 8 showed the relationship between prevalence of scabies with residential density, which resulted that overcrowded residential was more related to the infestation. Overcrowded living condition has the chance of being infestated 24.2 times higher than the ideal living space.

Table 8. The Relationship of Residential Density with Scabies Incidence $(\mathrm{N}=93)$

\begin{tabular}{|l|c|c|c|c|c|c|c|c|}
\hline \multirow{3}{*}{ Age } & \multicolumn{4}{|c|}{ Scabies } & \multicolumn{2}{c|}{ Total } & & \\
\cline { 2 - 5 } \cline { 5 - 9 } & \multicolumn{2}{|c|}{ Positive } & \multicolumn{2}{|c|}{ Negative } & \multicolumn{2}{c|}{ number } & $\boldsymbol{p}$-value & OR \\
\cline { 2 - 9 } & $\mathbf{n}$ & $\mathbf{\%}$ & $\mathbf{n}$ & $\mathbf{\%}$ & $\mathbf{n}$ & $\mathbf{\%}$ & & \\
\hline Overcrowded & 44 & 88 & 6 & 12 & 50 & 100 & & 24.2 \\
\hline Ideal density & 10 & 23.3 & 33 & 76.7 & 43 & 100 & 0.001 & $(7.990-73.299)$ \\
& & & & & & & & \\
\hline
\end{tabular}

From the results of this study, the prevalence of scabies at two Islamic boarding schools in South Sumatra, namely at $59.6 \%$ in the Raudatul Ulum Islamic Boarding School and $56.5 \%$ in Muqimus sunnah Islamic Boarding School. High risks for populations tend to be of high prevalence, such as Thai orphanages (87\%) [18], Korean lepraarium (87\% [19], rural villages in Papua New Guinea (80\%) [20], refugee camps in Sierra Leone ( 67\%) [21], and Islamic religious schools in Bangladesh (61\%) [22]. If the prevalence of scabies is related to gender, men are at 5,580 times higher risk than women and there is a significant relationship. Sex distribution Scabies are not uniform all over the world, and more distribution in boys than girls is reported to suffer from scabies without significant differences [23].

In a serological survey among Orang Asli in Malaysia, no significant differences were found between positive levels in men and women [24]. Young age remains a significant 
independent risk factor for the presence of scabies. Young adults are more at risk of scabies 7,750 times than older students. A higher prevalence in children than in adults may be due to a greater likelihood of close contact. education has a significant influence on the incidence of scabies, students with junior high school education are at risk of 6.213 times than students who have a high school education. The incidence of skin and scabies infections is often presented in pediatric clinics [25,26]. Scabies occurs in uninformed populations, such as in disadvantaged households, and homeless people [22]. The higher disease burden seems to be related to crowded living conditions.

The condition of dense crowded living room for santri is 24.2 times higher than the conditions of the santri room that meets the requirements. Occupancy density is an important factor in the incidence of scabies, several related studies in Mali, India and northern Australia shows a significant association of occupancy densities against scabies [27-29]. Several studies have suggested higher rates in urban areas and an increased incidence during winter [11]. Winter can drive density [30]. Using a bed the night before that was filled with a bed would risk a higher infection [31]. Scabies has become a major problem that led to the outbreak of war.

\section{Conclusion}

There was a relation of respondent characteristics and residential density to scabies prevalence in students of boarding school. The significant relationship of residential density, gender, level of education and age towards the occurrence of scabies should be further investigated in order to prepare for elimination programs.

\section{Acknowledgments}

The authors would like to thank the teachers and students of Raudatul Ulum and Muqimus Sunnah Boarding School for volunteering to support the research, also head and staff of Public Health Centre (Puskesmas) of Indralaya South Sumatra for diagnosing and treating the patients.

\section{Reference}

1. Hay R, Steer A, Engelman D and Walton S . J. Microbiol. Infect.18 (2012)

2. Romani L, Koroivueta J, Steer A C, Kama M, Kaldor J M, Wand H, Hamid M and Whitfeld M J. J. Trop. Dis 91 (2015)

3. Karimkhani C, Colombara D V., Drucker A M, Norton S A, Hay R, Engelman D, Steer A, Whitfeld M, Naghavi M and Dellavalle R P 2. J. Lancet Infect. Dis 17 (2017)

4. Jackson A, Heukelbach J, Filho A F D S, Campelo E D B and Feldmeier H. J. Med. Int. Heal 12 (2007)

5. Marotta M, Toni F, Dallolio L, Toni G and Leoni E. J. Infect. Control 1 (2018)

6. Leistner R, Buchwald D, Beyer M and Philipp S 2. J. Infect. Prev.18 (2017)

7. Feldmeierr H, Jackson A, Ariza L, Calheiros C M L, Soares V de L, Oliveira F A, Hengge U R and Heukelbach J. J. Am. Acad. Dermatology 60 (2008)

8. Sweileh W M. J. Infect. Dis. Poverty 7 (2018)

9. Wang C H, Lee S C, Huang S S, Kao Y C, See L C and Yang S H. J. Microbiol. Immunol. Infect 45 (2012) 
10. Heukelbach J, Mazigo H D and Ugbomoiko U S. J. Opin. Infect. Dis 26

Christophersen J 1978 The epidemiology of scabies in Denmark, 1900 to 1975 Arch. Dermatology 114 (2013)

11. Engelman D, Kiang K, Chosidow O, McCarthy J, Fuller C, Lammie P, Hay R and Steer A. J. Trop. Dis 7 (2013)

12. Arlian L G. J. Rev. Entomol.34 139-61(1989)

13. Mclean F E. J. Dermatol 52 (2013)

14. Heukelbach J and Feldmeier H. J. Scabies Lancet 367 (2006)

15. Yeoh D K, Anderson A, Cleland G and Bowen A C. J. Trop. Dis 11 (2017)

16. Ferdinand F, Thaha A, Rusmawardiana R and Tjekyan R M S. J. Kedokt. Sriwij 46 (2014)

17. Pruksachatkunakorn C, Wongthanee A and Kasiwat V. J. Pediatr. Int 45 (2003)

18. Park H, Lee C, Park S, Kwon H and Kweon S S. J. Trop. Med. Hyg 95 (2016)

19. Bockarie M J, Alexander N D E, Kazura J W, Bockarie F, Griffin L and Alpers M P. J. Acta Trop 75 (2000)

20. Terry B C, Kanjah F, Sahr F, Kortequee S, Dukulay I and Gbakima A A. J. Public Health 115 (2001)

21. Karim S A, Anwar K S, Khan M A H, Mollah M A H, Nahar N, Rahman H E M R, Mamun M Al, Goni N, Hossain M M, Rahman M S, Begum H and Das S K Bangladesh Public Health (2007)

22. Nazari M and Azizi A. J. Health (Irvine. Calif) 6 (2006)

23. Muhammad Zayyid M, Saidatul Saadah R, Adil A R, Rohela M and Jamaiah I. J. Biomed 27 (2010)

24. Lydeamore M J, Campbell P T, Cuningham W, Andrews R M, Kearns T, Clucas D, Gundjirryirr Dhurrkay R, Carapetis J, Tong S Y C, McCaw J M and McVernon J . J. Infect 146 (2018)

25. Thu P, Aung Z, Cuningham W, Hwang K, Andrews R M, Carapetis R, Kearns T, Clucas D, Mcvernon J, Simpson A, Tong S Y C and Campbell P T 2. J. PLoS Negl Trop Dis (2018)

26. Heukelbach J, Wilcke T, Winter B and Feldmeier H. J. Dermatol 153 (2005)

27. Currie B J, Connors C M and Krause V L. J. Aust 161 (1994)

28. Landwehr D, Keita S M, Pönnighaus J M and Tounkara C. J. Dermatol 37 (1998)

29. Kimchi N, Green M S and Stone D. J. Dermatol 28 (1989)

30. Downs A M R, Harvey I and Kennedy C T C. J. Infect 122 (1999) 